Published in final edited form as:

Ageing Res Rev. 2008 January ; 7(1): 43-48.

\title{
Dietary Factors, Hormesis and Health
}

\author{
Mark P. Mattson \\ Laboratory of Neurosciences, National Institute on Aging Intramural Research Program, 5600 \\ Nathan Shock Drive, Baltimore, MD 21224
}

\begin{abstract}
The impact of dietary factors on health and longevity is increasingly appreciated. The most prominent dietary factor that affects the risk of many different chronic diseases is energy intake - excessive calorie intake increases the risk. Reducing energy intake by controlled caloric restriction or intermittent fasting increases lifespan and protects various tissues against disease, in part, by hormesis mechanisms that increase cellular stress resistance. Some specific dietary components may also exert health benefits by inducing adaptive cellular stress responses. Indeed, recent findings suggest that several heavily studied phytochemicals exhibit biphasic dose responses on cells with low doses activating signaling pathways that result in increased expression of genes encoding cytoprotective proteins including antioxidant enzymes, protein chaperones, growth factors and mitochondrial proteins. Examples include: activation of the Nrf-2 - ARE pathway by sulforaphane and curcumin; activation of TRP ion channels by allicin and capsaicin; and activation of sirtuin-1 by resveratrol. Research that establishes dose response and kinetic characteristics of the effects of dietary factors on cells, animals and humans will lead to a better understanding of hormesis and to improvements in dietary interventions for disease prevention and treatment.
\end{abstract}

\section{Keywords}

adaptive stress response; exercise; histone deacetylase; phytochemicals; preconditioning; toxic

\section{Introduction}

There is a vast literature that describes the effects of various dietary factors on health and longevity. In some cases, there is incontrovertible evidence of a cause-and-effect relationship between a dietary factor and health, while in many other cases the link is inconclusive. Among dietary factors, the amount of calories consumed has been unequivocally and causally associated with the risk of many prominent age-related diseases (Barger et al., 2003; Smith et al., 2004; Martin et al., 2006). Put simply, high energy intake increases, while low energy intake decreases, the risks of cardiovascular disease, type 2 diabetes, stroke, cancers and possibly neurodegenerative disorders. Regarding specific dietary components, saturated fats, cholesterol and trans-fats may promote age-related disease (Grundy, 1999; Wijendran and Hayes, 2004), while diets high in simple sugars increase the risk of diabetes (Schulze and $\mathrm{Hu}$, 2005). Other data suggest health benefits of diets rich in vegetables and fruits (Heber, 2004), fish (Carpentier et al., 2006) and nuts (Hu and Stampfer, 1999). Because oxidative stress is believed to play a major role in the ageing process and in the diseases most commonly responsible for mortality, there is considerable interest in whether dietary factors influence

Correspondence: Mark P. Mattson. Email: mattsonm@grc.nia.nih.gov.

Publisher's Disclaimer: This is a PDF file of an unedited manuscript that has been accepted for publication. As a service to our customers we are providing this early version of the manuscript. The manuscript will undergo copyediting, typesetting, and review of the resulting proof before it is published in its final citable form. Please note that during the production process errors may be discovered which could affect the content, and all legal disclaimers that apply to the journal pertain. 
disease processes and longevity primarily by modifying oxidative stress. Indeed, evidence supports anti-oxidative effects of dietary energy restriction (DER) and chemicals present in vegetables, fruits, nuts and fish oils (Simopoulos, 2001).

In the present article I focus on the issue of if, and to what extent, hormesis mechanisms mediate health benefits of various dietary factors, with a focus on DER and phytochemicals. Examples of animal and cell culture data supporting hormetic features of biological actions of dietary factors are presented, together with findings that elucidate specific adaptive stress response signaling pathways that mediate dietary factor-induced hormesis.

\section{Dietary Energy Intake and Hormesis}

There is also considerable evidence from highly controlled studies of laboratory animals that DER (either controlled caloric restriction or intermittent fasting) can increase the resistance of cells in the animals to various types of stress. For example, mortality from natural causes or that caused by thermal and oxidative stress exposures to specific toxins is significantly reduced in animals that have been maintained on DER compared to control animals consuming a normal diet (Fernandes et al., 1976; Hall et al., 2000; Vasselli et al., 2005; Lee et al., 2006). DER protects rodents against cancers induced in a wide range of tissues and by many different carcinogens including pancreatic tumors induced by azaserine (Roebuck et al., 1981), mammary tumors induced by DMBA (Klurfeld et al., 1989) and prostate cancer induced by $\mathrm{N}$-methyl-N-nitrosourea and testosterone (Boileau et al., 2003). DER was effective in protecting heart and brain cells against ischemic injury in models of myocardial infarction and stroke (Yu and Mattson,1999; Ahmet et al., 2005). Nerve cells in the brains of animals maintained on DER exhibited increased resistance to neurotoxins in experimental models relevant to epilepsy, Huntington's disease, Parkinson's disease and Alzheimer's disease (Bruce-Keller et al., 1999; Duan and Mattson, 1999; Halagappa et al., 2007). Studies of humans also suggest that DER can counteract disease processes. For example, alternate day fasting improved symptoms and reduced markers of inflammation and oxidative stress in asthma subjects (Johnson et al., 2007).

Studies have revealed several biochemical and molecular changes in animals maintained on DER regimens that are consistent with the involvement of hormesis mechanisms in the beneficial effects of DER for health. Levels of heat-shock proteins, which serve a chaperone function that protects proteins against damage, have been shown to be increased in several different tissues from animals maintained on DER. For example, levels of HSP-70 are increased in liver cells of rats maintained on caloric restriction (Heydari et al., 1993) and intermittent fasting results in increased levels of HSP-70 and glucose-regulated protein 78 in synapses in the brains of rats (Guo et al., 2000). Another category of cytoprotective molecules upregulated by DER is antioxidants. Diabetic rodents maintained on DER exhibit increased levels of some antioxidant enzymes in their liver (Ugochukwu and Figgers, 2007). In addition, rats maintained on a reduced calorie diet exhibit greater amounts of vitamin $\mathrm{E}$ and coenzyme Q10, and higher plasma membrane redox enzyme activities, in brain cell membranes compared to control rats fed ad libitum (Hyun et al., 2006). Upregulation of antioxidant mechanisms as one hormetic mechanism of action of DER is consistent with numerous reports of reduced oxidative damage to proteins, lipids and DNA in various tissues of animals on DER (Sanz et al., 2006). Hormetic effects of DER may also involve changes in systems that regulate cellular energy metabolism. For example, various cell types respond to DER by upregulating the expression of proteins involved in the regulation of mitochondrial oxidative phosphorylation (Liu et al., 2006), glycolysis (Rodgers et al., 2005) and NAD/NADH metabolism (Hyun et al., 2006).

Growth factors play fundamental roles in regulating cellular hormesis within and across tissues, and are particularly important in the transfer of adaptive stress response signals between cells 
during conditions of tissue injury and potentially toxic environmental conditions. An increase in the production of growth factors typically occurs in cells subjected to mild hormetic types of stress. For example, mild ischemia induces the expression of vascular endothelial cell growth factor (VEGF) in both the heart (Kawata et al., 2001) and the brain (Bernaudin et al., 2002), and electroconvulsive shock (a treatment for some psychiatric disorders) increases the production of basic fibroblast growth factor (bFGF; Gwinn et al., 2002) and brain-derived neurotrophic factor (BDNF; Newton et al., 2003). These stress-responsive growth factors are known to activate signaling pathways that protect cells against oxidative and metabolic damage (Mattson and Scheff, 1994). When rodents or monkeys are maintained on DER, levels of BDNF and glial cell line-derived neurotrophic factor (GDNF) are increased in several regions of the brain (Lee et al., 2002; Maswood et al., 2004). It is believed that these neurotrophic factors can protect neurons against various types of stress and may, by hormetic mechanisms, protect against diseases such as Parkinson's and Huntington's diseases (Duan et al., 2003a; Maswood et al., 2004). In addition to DER, BDNF expression is increased in the brain in response to exercise and some evidence suggests that BDNF signaling in the brain can enhance peripheral insulin sensitivity, thereby protecting against the development of diabetes (Duan et al., 2003a; Mattson et al., 2004). Finally, it should be noted the DER decreases levels of some growth factors including insulin and IGF-1 (Breese et al., 1991; Sell, 2003). However, associated with the decreased levels of these growth factors is increased sensitivity of cells to the growth factors. Thus, enhanced growth factor signaling can occur without an increase (or even with a decrease) in levels of the ligand.

Interestingly, DER may not induce a hormetic response in all cell types. For example, motor neurons in the spinal cord fail to upregulate HSP-70 and do not benefit from DER in a mouse model of amyotrophic lateral sclerosis (Mattson et al., 2007). Cells involved in wound healing may not respond adaptively to DER and, indeed, it has been reported the DER can impair wound healing in rodents (Reiser et al., 1995). Depending upon the magnitude of energy restriction, DER may not benefit, or even adversely affect, reproductive organs, particularly in females (Martin et al., 2007). However, careful dose response studies of the effects of DER on various cell types and organ systems have not been performed; such analyses will be critical for establishing the hormetic range of DER and for developing DER regimens that are optimal for health in humans.

\section{Dietary Phytochemicals and Hormesis}

The now compelling evidence for biphasic dose response effects of environmental "toxins" in biological systems suggests the possibility that chemicals in foodstuffs (particularly plants) might also exert biphasic dose responses with health benefits resulting from ingestion of the chemicals in doses within the hormetic range. During evolution plants developed biosynthetic pathways for the production of toxins that prevent microorganisms and insects from eating them. Indeed, more than 100 such biopesticides involved in plant defense have been identified (Trewavas and Stewart, 2003). Such noxious chemicals are typically concentrated in exposed vulnerable regions of the plant such as the skin of fruits and the growing buds. At high concentrations such phytochemicals can be toxic to mammalian cells. However, subtoxic doses may induce adaptive stress responses. Hormetic mechanisms of action of specific phytochemicals have been suggested in studies of various cell types. Examples include: isothocyanates present at high levels in broccoli induced the expression of cytoprotective phase 2 proteins in liver, intestinal and stomach cells (McWalter et al., 2004); the curry spice curcumin has been reported to induce adaptive stress response genes and protect cells in animal models of cataract formation, pulmonary toxicity, multiple sclerosis and Alzheimer's disease (Shishodia et al., 2007); and resveratrol (a chemical present in the skin of red grapes and wine) can activate stress response pathways and protect cells in models of myocardial infarction and 
stroke (Baur and Sinclair, 2006). However, high doses of these phytochemicals can also be toxic to some types of cells (Liontas and Yeger, 2004; Fimognari et al., 2005).

Because they often exhibit antioxidant activity, it has been widely assumed that the direct free radical scavenging activity of phytochemicals confers their health benefits (Prior, 2003).

However, it is unclear, and in most cases unlikely, that humans ingest the fruits and vegetables that contain these phytochemicals in amounts sufficient to achieve the high (micromolar) concentrations of the phytochemicals required to scavenge free radicals. Indeed, finding from epidemiological studies and clinical trials have failed to demonstrate benefits of dietary supplementation with antioxidants such as vitamins E and C (Williams and Fisher, 2005). Instead, emerging evidence suggests that hormetic mechanisms of action may underlie many of the health benefits of phytochemicals.

Specific signal transduction pathways that mediate the hormetic actions of several phytochemicals have been elucidated. One pathway involves the transcription factor Nrf-2 which binds the antioxidant response element (ARE) upstream of genes encoding cytoprotective antioxidant enzymes and phase- 2 proteins. The latter pathway is activated by curcumin, sulforaphane (present in broccoli) and allicin (present in garlic) (Dinkova-Kostova et al., 2002; Balogun et al., 2003; Chen et al., 2004). Other phytochemicals may activate the sirtuin - FOXO pathway resulting in increased expression of antioxidant enzymes and cell survival-promoting proteins; resveratrol has been shown to activate this pathway (Frescas et al., 2005). Ingestion of other phytochemicals may activate the hormetic transcription factors $\mathrm{NF}-\mathrm{KB}$ and CREB resulting in the induction of genes encoding growth factors and antiapoptotic proteins (Mabuchi et al., 2001; Mattson and Meffert, 2006).

\section{Outlook}

The emerging evidence that DER and specific chemical components of the diet can elicit hormetic responses in various types of cells opens new avenues for both basic and applied research in the fields of nutrition, ageing and disease. Oft avoided, in vivo dose response studies are essential for establishing whether dietary factor is indeed exerting its effects on organisms and cells by a hormetic mechanism. In addition, frequency of exposure to the diets should be evaluated as intermittent exposures to DER and phytochemicals may prove superior to more frequent exposures. Evidence for increased stress resistance associated with activation of adaptive stress response pathways in cells should be established. Finally, DER and phytochemicals should be tested in experimental models of disease, and consensus recommendations for their consumption either in foods themselves or as dietary supplements, should be developed. In order to achieve these goals, the efforts of an array of scientists, health professionals and government agencies will be required.

\section{Acknowledgements}

Supported by the Intramural Research Program of the National Institute on Aging, NIH.

\section{References}

Ahmet I, Wan R, Mattson MP, Lakatta EG, Talan M. Cardioprotection by intermittent fasting in rats. Circulation 2005;112:3115-3121. [PubMed: 16275865]

Balogun E, Hoque M, Gong P, Killeen E, Green CJ, Foresti R, Alam J, Motterlini R. Curcumin activates the haem oxygenase-1 gene via regulation of Nrf2 and the antioxidant-responsive element. Biochem J 2003;371:887-895. [PubMed: 12570874]

Barger JL, Walford RL, Weindruch R. The retardation of aging by caloric restriction: its significance in the transgenic era. Exp Gerontol 2003;38:1343-1351. [PubMed: 14698815] 
Baur JA, Sinclair DA. Therapeutic potential of resveratrol: the in vivo evidence. Nat Rev Drug Discov 2006;5:493-506. [PubMed: 16732220]

Boileau TW, Liao Z, Kim S, Lemeshow S, Erdman JW Jr, Clinton SK. Prostate carcinogenesis in Nmethyl-N-nitrosourea (NMU)-testosterone-treated rats fed tomato powder, lycopene, or energyrestricted diets. J Natl Cancer Inst 2003;95:1578-1586. [PubMed: 14600090]

Breese CR, Ingram RL, Sonntag WE. Influence of age and long-term dietary restriction on plasma insulinlike growth factor-1 (IGF-1), IGF-1 gene expression, and IGF-1 binding proteins. J Gerontol 1991;46:B180-187. [PubMed: 1716275]

Bruce-Keller AJ, Umberger G, McFall R, Mattson MP. Food restriction reduces brain damage and improves behavioral outcome following excitotoxic and metabolic insults. Ann Neurol 1999;45:8-15. [PubMed: 9894871]

Carpentier YA, Portois L, Malaisse WJ. n-3 fatty acids and the metabolic syndrome. Am J Clin Nutr 2006;83:1499S-1504S. [PubMed: 16841860]

Chen C, Pung D, Leong V, Hebbar V, Shen G, Nair S, Li W, Kong AN. Induction of detoxifying enzymes by garlic organosulfur compounds through transcription factor Nrf2: effect of chemical structure and stress signals. Free Radic Biol Med 2004;37:1578-1590. [PubMed: 15477009]

Dinkova-Kostova AT, Holtzclaw WD, Cole RN, Itoh K, Wakabayashi N, Katoh Y, Yamamoto M, Talalay P. Direct evidence that sulfhydryl groups of Keap1 are the sensors regulating induction of phase 2 enzymes that protect against carcinogens and oxidants. Proc Natl Acad Sci U S A 2002;99:1190811913. [PubMed: 12193649]

Duan W, Mattson MP. Dietary restriction and 2-deoxyglucose administration improve behavioral outcome and reduce degeneration of dopaminergic neurons in models of Parkinson's disease. J Neurosci Res 1999;57:195-206. [PubMed: 10398297]

Duan W, Guo Z, Jiang H, Ware M, Mattson MP. Reversal of behavioral and metabolic abnormalities, and insulin resistance syndrome, by dietary restriction in mice deficient in brain-derived neurotrophic factor. Endocrinology 2003b;144:2446-2453. [PubMed: 12746306]

Duan W, Guo Z, Jiang H, Ware M, Li XJ, Mattson MP. Dietary restriction normalizes glucose metabolism and BDNF levels, slows disease progression, and increases survival in huntingtin mutant mice. Proc Natl Acad Sci U S A 2003b;100:2911-2916. [PubMed: 12589027]

Fernandes G, Yunis EJ, Good RA. Influence of diet on survival of mice. Proc Natl Acad Sci U S A 1976;73:1279-1283. [PubMed: 1063408]

Fimognari C, Berti F, Iori R, Cantelli-Forti G, Hrelia P. Micronucleus formation and induction of apoptosis by different isothiocyanates and a mixture of isothiocyanates in human lymphocyte cultures. Mutat Res 2005;582:1-10. [PubMed: 15781204]

Frescas D, Valenti L, Accili D. Nuclear trapping of the forkhead transcription factor FoxO1 via Sirtdependent deacetylation promotes expression of glucogenetic genes. J Biol Chem 2005;280:20589_ 20595. [PubMed: 15788402]

Guo Z, Ersoz A, Butterfield DA, Mattson MP. Beneficial effects of dietary restriction on cerebral cortical synaptic terminals: preservation of glucose and glutamate transport and mitochondrial function after exposure to amyloid beta-peptide, iron, and 3-nitropropionic acid. J Neurochem 2000;75:314-320. [PubMed: 10854276]

Grundy SM. The optimal ratio of fat-to-carbohydrate in the diet. Annu Rev Nutr 1999;19:325-341. [PubMed: 10448527]

Halagappa VK, Guo Z, Pearson M, Matsuoka Y, Cutler RG, Laferla FM, Mattson MP. Intermittent fasting and caloric restriction ameliorate age-related behavioral deficits in the triple-transgenic mouse model of Alzheimer's disease. Neurobiol Dis 2007;26:212-220. [PubMed: 17306982]

Hall DM, Oberley TD, Moseley PM, Buettner GR, Oberley LW, Weindruch R, Kregel KC. Caloric restriction improves thermotolerance and reduces hyperthermia-induced cellular damage in old rats. FASEB J 2000;14:78-86. [PubMed: 10627282]

Heber D. Vegetables, fruits and phytoestrogens in the prevention of diseases. J Postgrad Med 2004;50:145-149. [PubMed: 15235216]

Heydari AR, Wu B, Takahashi R, Strong R, Richardson A. Expression of heat shock protein 70 is altered by age and diet at the level of transcription. Mol Cell Biol 1993;13:2909-2918. [PubMed: 7682654] 
Hu FB, Stampfer MJ. Nut consumption and risk of coronary heart disease: a review of epidemiologic evidence. Curr Atheroscler Rep 1999;1:204-209. [PubMed: 11122711]

Hyun DH, Emerson SS, Jo DG, Mattson MP, de Cabo R. Calorie restriction up-regulates the plasma membrane redox system in brain cells and suppresses oxidative stress during aging. Proc Natl Acad Sci U S A 2006;103:19908-19912. [PubMed: 17167053]

Johnson JB, Summer W, Cutler RG, Martin B, Hyun DH, Dixit VD, Pearson M, Nassar M, Tellejohan R, Maudsley S, Carlson O, John S, Laub DR, Mattson MP. Alternate day calorie restriction improves clinical findings and reduces markers of oxidative stress and inflammation in overweight adults with moderate asthma. Free Radic Biol Med 2007;42:665-674. [PubMed: 17291990]

Kawata H, Yoshida K, Kawamoto A, Kurioka H, Takase E, Sasaki Y, Hatanaka K, Kobayashi M, Ueyama T, Hashimoto T, Dohi K, Kawata H, Yoshida K, Kawamoto A, Kurioka H, Takase E, Sasaki Y, Hatanaka K, Kobayashi M, Ueyama T, Hashimoto T, Dohi K. Ischemic preconditioning upregulates vascular endothelial growth factor mRNA expression and neovascularization via nuclear translocation of protein kinase C epsilon in the rat ischemic myocardium. Circ Res 2001;88:696704. [PubMed: 11304492]

Klurfeld DM, Welch CB, Lloyd LM, Kritchevsky D. Inhibition of DMBA-induced mammary tumorigenesis by caloric restriction in rats fed high-fat diets. Int J Cancer 1989;43:922-925. [PubMed: 2497075]

Lee J, Duan W, Mattson MP. Evidence that brain-derived neurotrophic factor is required for basal neurogenesis and mediates, in part, the enhancement of neurogenesis by dietary restriction in the hippocampus of adult mice. J Neurochem 2002;82:1367-1375. [PubMed: 12354284]

Lee GD, Wilson MA, Zhu M, Wolkow CA, de Cabo R, Ingram DK, Zou S. Dietary deprivation extends lifespan in Caenorhabditis elegans. Aging Cell 2006;5:515-524. [PubMed: 17096674]

Liontas A, Yeger H. Curcumin and resveratrol induce apoptosis and nuclear translocation and activation of p53 in human neuroblastoma. Anticancer Res 2004;24:987-998. [PubMed: 15161054]

Liu D, Chan SL, de Souza-Pinto NC, Slevin JR, Wersto RP, Zhan M, Mustafa K, de Cabo R, Mattson MP. Mitochondrial UCP4 mediates an adaptive shift in energy metabolism and increases the resistance of neurons to metabolic and oxidative stress. Neuromolecular Med 2006;8:389-414. [PubMed: 16775390]

Mabuchi T, Kitagawa K, Kuwabara K, Takasawa K, Ohtsuki T, Xia Z, Storm D, Yanagihara T, Hori M, Matsumoto M. Phosphorylation of cAMP response element-binding protein in hippocampal neurons as a protective response after exposure to glutamate in vitro and ischemia in vivo. J Neurosci 2001;21:9204-9213. [PubMed: 11717354]

Martin B, Mattson MP, Maudsley S. Caloric restriction and intermittent fasting: two potential diets for successful brain aging. Ageing Res Rev 2006;5:332-353. [PubMed: 16899414]

Martin B, Pearson M, Kebejian L, Golden E, Keselman A, Bender M, Carlson O, Egan J, Ladenheim B, Cadet JL, Becker KG, Wood W, Duffy K, Vinayakumar P, Maudsley S, Mattson MP. Sex-dependent metabolic, neuroendocrine and cognitive responses to dietary energy restriction and excess. Endocrinology. 2007 Jun 14;Epub ahead of print

Maswood N, Young J, Tilmont E, Zhang Z, Gash DM, Gerhardt GA, Grondin R, Roth GS, Mattison J, Lane MA, Carson RE, Cohen RM, Mouton PR, Quigley C, Mattson MP, Ingram DK. Caloric restriction increases neurotrophic factor levels and attenuates neurochemical and behavioral deficits in a primate model of Parkinson's disease. Proc Natl Acad Sci U S A 2004;101:18171-18176. [PubMed: 15604149]

Mattson MP, Scheff SW. Endogenous neuroprotection factors and traumatic brain injury: mechanisms of action and implications for therapy. J Neurotrauma 1994;11:3-33. [PubMed: 8201625]

Mattson MP, Maudsley S, Martin B. A neural signaling triumvirate that influences ageing and age-related disease: insulin/IGF-1, BDNF and serotonin. Ageing Res Rev 2004;3:445-464. [PubMed: 15541711]

Mattson MP, Meffert MK. Roles for NF-kappaB in nerve cell survival, plasticity, and disease. Cell Death Differ 2006;13:852-860. [PubMed: 16397579]

Mattson MP, Cutler RG, Camandola S. Energy intake and amyotrophic lateral sclerosis. Neuromolecular Med 2007;9:17-20. [PubMed: 17114821]

McWalter GK, Higgins LG, McLellan LI, Henderson CJ, Song L, Thornalley PJ, Itoh K, Yamamoto M, Hayes JD. Transcription factor Nrf2 is essential for induction of NAD(P)H:quinone oxidoreductase 
1, glutathione S-transferases, and glutamate cysteine ligase by broccoli seeds and isothiocyanates. J Nutr 2004;134:3499S-3506S. [PubMed: 15570060]

Newton SS, Collier EF, Hunsberger J, Adams D, Terwilliger R, Selvanayagam E, Duman RS. Gene profile of electroconvulsive seizures: induction of neurotrophic and angiogenic factors. J Neurosci 2003;23:10841-10851. [PubMed: 14645477]

Prior RL. Fruits and vegetables in the prevention of cellular oxidative damage. Am J Clin Nutr 2003;78:570S-578S. [PubMed: 12936951]

Reiser K, McGee C, Rucker R, McDonald R. Effects of aging and caloric restriction on extracellular matrix biosynthesis in a model of injury repair in rats. J Gerontol A Biol Sci Med Sci 1995;50A:B4047. [PubMed: 7814778]

Rodgers JT, Lerin C, Haas W, Gygi SP, Spiegelman BM, Puigserver P. Nutrient control of glucose homeostasis through a complex of PGC-1alpha and SIRT1. Nature 2005;434:113-118. [PubMed: 15744310]

Roebuck BD, Yager JD Jr, Longnecker DS. Dietary modulation of azaserine-induced pancreatic carcinogenesis in the rat. Cancer Res 1981;41:888-893. [PubMed: 7459874]

Sanz A, Pamplona R, Barja G. Is the mitochondrial free radical theory of aging intact? Antioxid Redox Signal 2006;8:582-599. [PubMed: 16677102]

Schulze MB, Hu FB. Primary prevention of diabetes: what can be done and how much can be prevented? Annu Rev Public Health 2005;26:445-467. [PubMed: 15760297]

Sell, Ch. Caloric restriction and insulin-like growth factors in aging and cancer. Horm Metab Res 2003;35:705-711. [PubMed: 14710349]

Shishodia S, Singh T, Chaturvedi MM. Modulation of transcription factors by curcumin. Adv Exp Med Biol 2007;595:127-148. [PubMed: 17569208]

Simopoulos AP. The Mediterranean diets: What is so special about the diet of Greece? The scientific evidence. J Nutr 2001;131:3065S-3073S. [PubMed: 11694649]

Smith JV, Heilbronn LK, Ravussin E. Energy restriction and aging. Curr Opin Clin Nutr Metab Care 2004;7:615-622. [PubMed: 15534428]

Ugochukwu NH, Figgers CL. Dietary caloric restriction improves the redox status at the onset of diabetes in hepatocytes of streptozotocin-induced diabetic rats. Chem Biol Interact 2007;165:45-53. [PubMed: 17123496]

Vasselli JR, Weindruch R, Heymsfield SB, Pi-Sunyer FX, Boozer CN, Yi N, Wang C, Pietrobelli A, Allison DB. Intentional weight loss reduces mortality rate in a rodent model of dietary obesity. Obes Res 2005;13:693-702. [PubMed: 15897478]

Wijendran V, Hayes KC. Dietary n-6 and n-3 fatty acid balance and cardiovascular health. Annu Rev Nutr 2004;24:597-615. [PubMed: 15189133]

Williams KJ, Fisher EA. Oxidation, lipoproteins, and atherosclerosis: which is wrong, the antioxidants or the theory? Curr Opin Clin Nutr Metab Care 2005;8:139-146. [PubMed: 15716791]

Yu ZF, Mattson MP. Dietary restriction and 2-deoxyglucose administration reduce focal ischemic brain damage and improve behavioral outcome: evidence for a preconditioning mechanism. J Neurosci Res 1999;57:830-839. [PubMed: 10467254] 


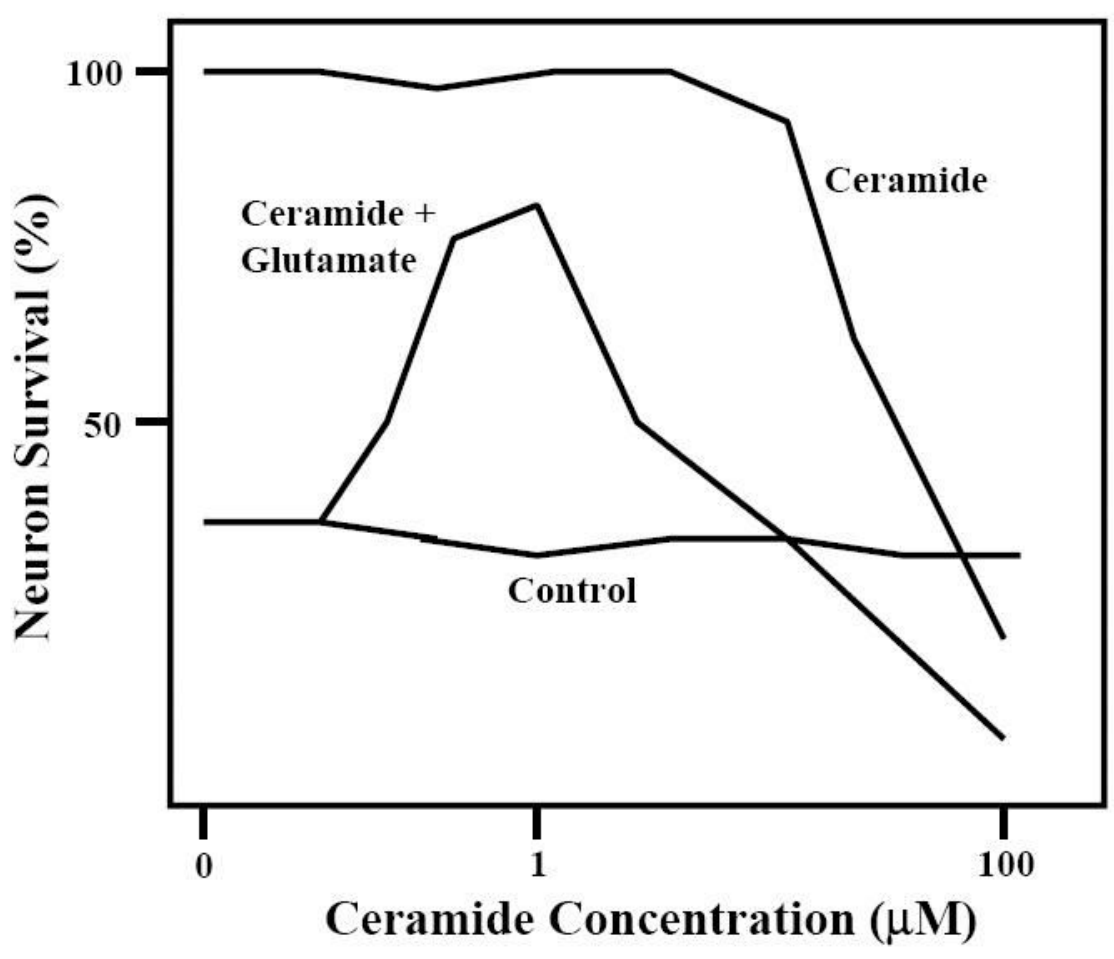

Figure 1. 


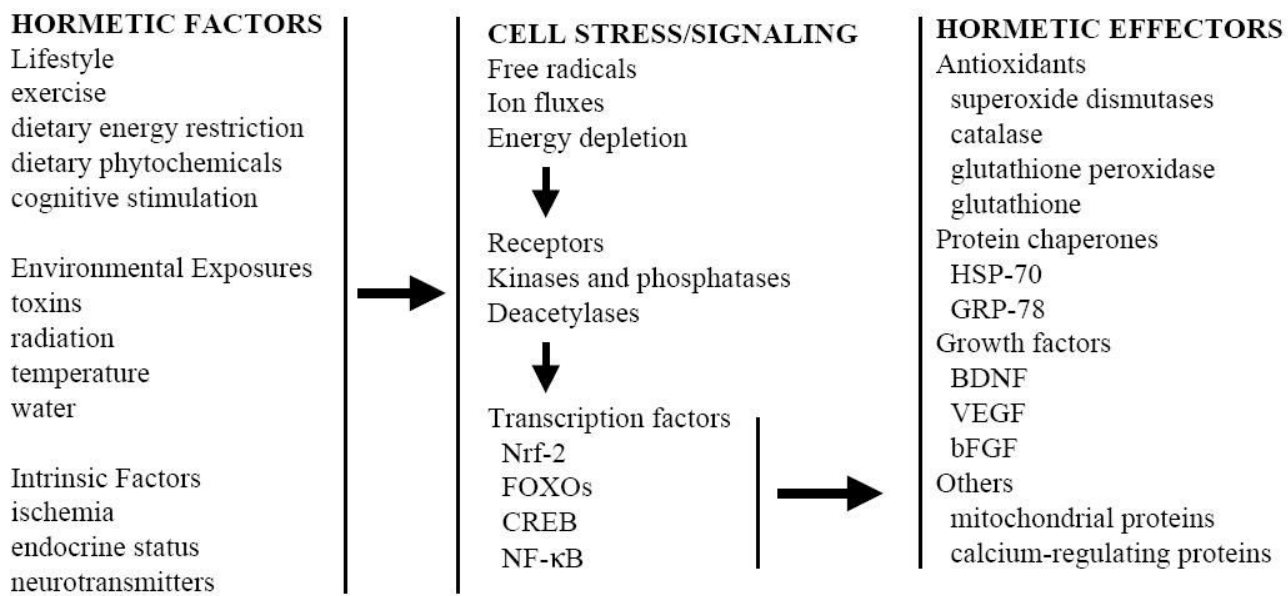

Figure 2. 

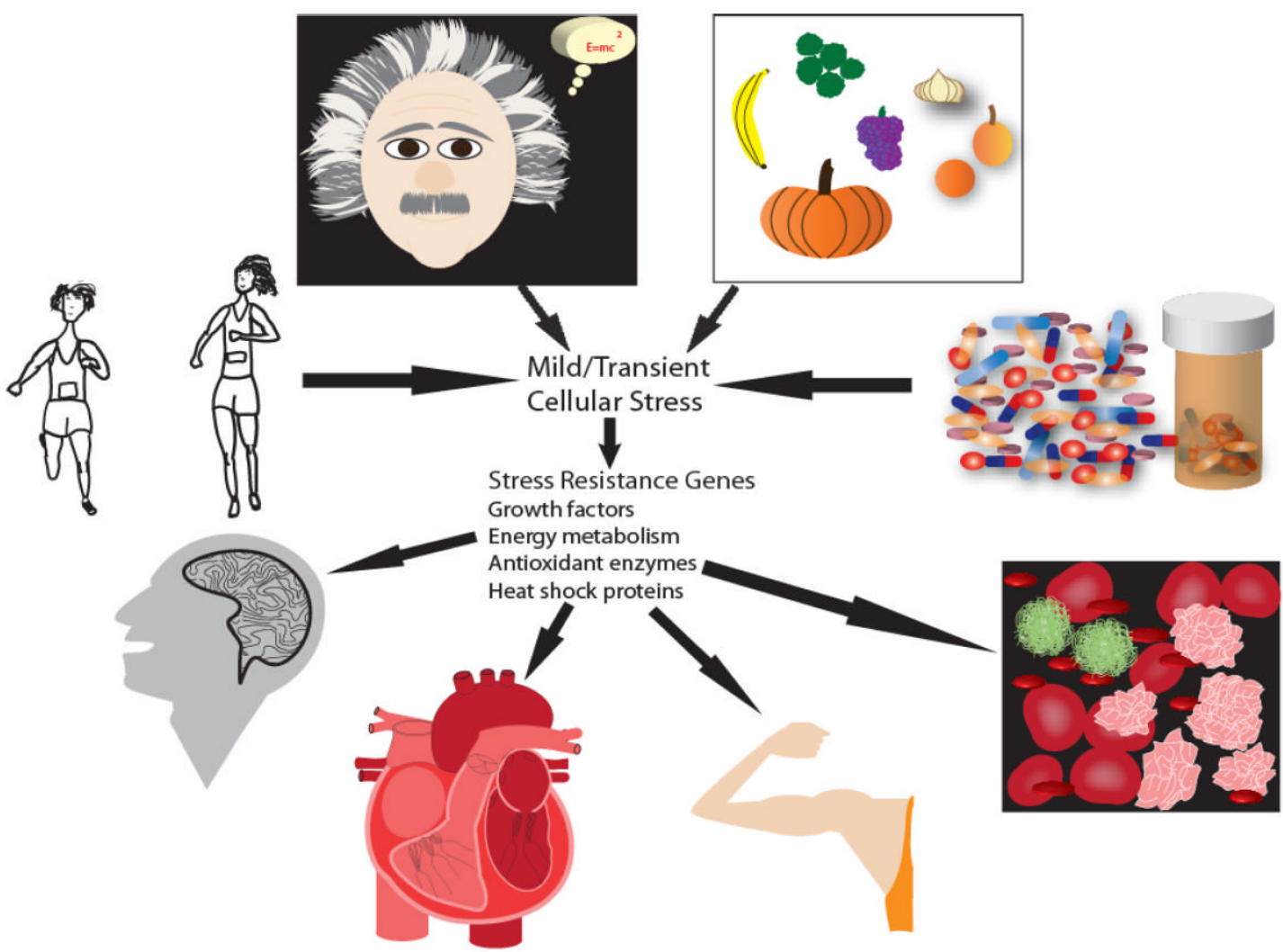

Optimum Mental, Cardiovascular, Neuromuscular and Immune Function Resistance to Diseases Including Diabetes, Cardiovascular and Neurological Disorders

Figure 3. 